\title{
Use of MTA in teeth with incomplete root formation or open foramina: introduction of a protocol and report of clinical cases
}

\author{
Uso de MTA em dentes com rizogênese incompleta ou forames abertos: apresentação de um protocolo e \\ relato de casos clinicos
}

\author{
Antônio Edgar KRÖLING ${ }^{1}$ \\ Carlos Roberto BERGER ${ }^{1}$ \\ Carlos Antônio PELLISSARI ${ }^{1}$ \\ Maicon Alves Junqueira GOMES²
}

\begin{abstract}
Apexification is the endodontic procedure performed in order to induce the formation of a physical barrier of mineralized tissue in teeth with incomplete root formation. It is mainly performed when, for any reason, pulpal necrosis occurs in teeth with incomplete root formation and also in those cases where the foramen is open, due to root resorption. In these situations, conventional endodontic treatment becomes difficult or virtually impossible, because of the large foramen. The apexification procedure, in these cases, is generally performed by means of successive changes of calcium hydroxide dressings, aiming to induce the formation of a physical barrier of mineralized tissue, thus permitting the obturation of root canals. The protocol introduced in this article, as well as the clinical cases reported, illustrate an option for faster treatment, conducted within three sessions, by using a MTA cap or plug, material that offers good biological and physical properties.
\end{abstract}

Indexing terms: Apexogenesis. Calcium hydroxide. Root canal therapy.

\section{RESUMO}

A apicificação é o procedimento endodôntico realizado para induzir a formação de uma barreira física de tecido mineralizado em dentes com incompleta formação radicular. É realizada, principalmente, quando, por alguma razão, ocorre necrose pulpar em dentes com rizogênese incompleta e, também, nos casos em que o forame se encontra aberto, em função de reabsorção radicular. Nessas situações, o tratamento endodôntico convencional se torna difícil ou quase impossível, por causa do amplo forame. O procedimento de apicificação, nesses casos, é geralmente realizado por meio de trocas sucessivas de curativos de hidróxido de cálcio, com o objetivo de induzir a formação de uma barreira física de tecido mineralizado, possibilitando, então, a obturação dos canais radiculares. O protocolo apresentado neste artigo, bem como os casos clínicos relatados, ilustram uma opção de tratamento mais rápido, realizado em três sessões, utilizando um tampão ou plug de MTA, material que oferece boas propriedades biológicas e físicas.

Termos de indexação: Apexificação. Hidróxido de cálcio. Tratamento do canal radicular.

\section{INTRODUCTION}

Young patients' teeth, due to various factors, may suffer pulp necrosis and a consequent cessation of root development. Root resorption may also occur, and it leads the tooth to have an open foramen, too. In both cases, these teeth have great difficulty or even impossibility for undergoing conventional endodontic treatment. Teeth with open foramen pose a challenge during a root canal treatment and little is known about the clinical follow-up in such cases.

The most usual procedure in these situations has been apexification with calcium hydroxide, as described by Frank, in 1966'. Before this date, these cases required a surgical procedure for placing and an apical seal of apices, often fragile.

Apexification is performed when there is clinical and radiographic evidence of pulp necrosis and the root, incompletely formed, has an apical diameter larger than the coronary diameter of the canal ${ }^{2}$.

Apexification procedures using calcium hydroxide have been historically used to establish apical closure and prevent surgery'.

Despite the good rates of clinical success using the technique of apexification with calcium hydroxide, there are some disadvantages. Treatment requires greater patient commitment and multiple sessions, thus extending over a lengthy period of time. In addition to unpredictable apical

\footnotetext{
${ }^{1}$ Universidade Estadual de Ponta Grossa, Setor de Ciências Biológicas e da Saúde, Departamento de Odontologia. Praça Santos Andrade, S/N, Centro, 8401090, Ponta Grossa, PR, Brasil. Correspondência para / Correspondence to: AE KRÖLING. E-mail: <edgarkroling@yahoo.com.br>.

2 Associação Brasileira de Odontologia, Secção de Ponta Grossa. Ponta Grossa, PR, Brasil.
} 
closure, other negative factors include conflicts in patient follow-up, financial interests, aesthetic expectations, and susceptibility to coronal leakage or fracture ${ }^{3-4}$.

An alternative to the apexification procedure in multiple sessions has been a simple technique by using an apical physical barrier. Many materials have been proposed for this purpose and their biocompatibility and osteogenic potential have been demonstrated ${ }^{3,5}$.

Recently, a one-session technique using mineral trioxide aggregate (MTA) has gained popularity when compared to apexification with calcium hydroxide in multiple sessions ${ }^{6-7}$.

The reason to choose MTA as a material for orthograde canal obturation instead of apexification with calcium hydroxide, in multiple sessions, is due to its excellent biocompatibility, as well as its superior sealing capacity and marginal adaptation ${ }^{8-9}$.

This article aims to introduce the clinical protocol used in the Specialization Course in Endodontics of Escola de Aperfeiçoamento Profissional of Associação Brasileira de Odontologia de Ponta Grossa and, also, report some clinical cases.

\section{Clinical protocol}

The clinical protocol used in the Specialization Course in Endodontics of Escola de Aperfeiçoamento Profissional of Associação Brasileira de Odontologia de Ponta Grossa for using a MTA plug is executed in three sessions.

First session: 1) anesthesia, removal of carious tissue, absolute isolation; b) access to the pulp chamber, canal emptying, odontometry, and root canal biomechanics, irrigating with $1 \%$ sodium hypochlorite or $2 \%$ chlorhexidine gel, and saline; 3 ) placement of intracanal medication, calcium hydroxide paste with saline, water soluble vehicle, added with iodoform (to provide radiopacity), for a period of 15 days; and d) coronal sealing with a suitable temporary cement.

Second session: 1) canal irrigation with $1 \%$ sodium hypochlorite, under absolute isolation; 2) canal drying with paper towels; 3) MTA preparation with distilled water; 4) material insertion and slight compaction of it with suitable pushers, in this case, digital spacers with a cut-down end, at a length of 3 to $5 \mathrm{~mm}$ below the working length, so that a plug is formed having this thickness; 5) immediate radiographic control to check the correct filling of the canal's apical portion; and 6) sealing the tooth with a provisional suitable material, for 24 hours.

Third session: 1) removal of provisional sealing and little cotton ball, under absolute isolation; 2) root canal obturation, using a rolled gutta-percha cone and an obturation cement; 3) definitive restoration; 4) clinical and radiographic control, after 3 and 6 months, until observing the formation of an apical hard tissue barrier and recovery from injuries, when there is any; and 5) radiographic control every 12 months until it is deemed unnecessary.

\section{CLINICAL CASES}

\section{Clinical case 1}

Male patient, 16 years old, sought the Endodontics Clinic of Escola de Aperfeiçoamento Profissional of Associação Brasileira de Odontologia de Ponta Grossa on $11 / 21 / 2003$. According to the patient, he wanted to treat a tooth that was open. During anamnesis, the patient reported a fall about 5 years ago, but failed to recall details. He only reported feeling some pain 2 years ago, but did not sought professional care. During clinical examination, we observed coronal fracture at the incisal third, with dimming, absence of pain on vertical and horizontal percussion and, also, on palpation. The tooth did not respond to pulp sensitivity test. Radiographically, it showed periapical radiolucency, with open foramen.

The patient underwent treatment, according to the protocol used by the Specialization Course in Endodontics of Escola de Aperfeiçoamento Profissional of Associação Brasileira de Odontologia de Ponta Grossa, as previously described.
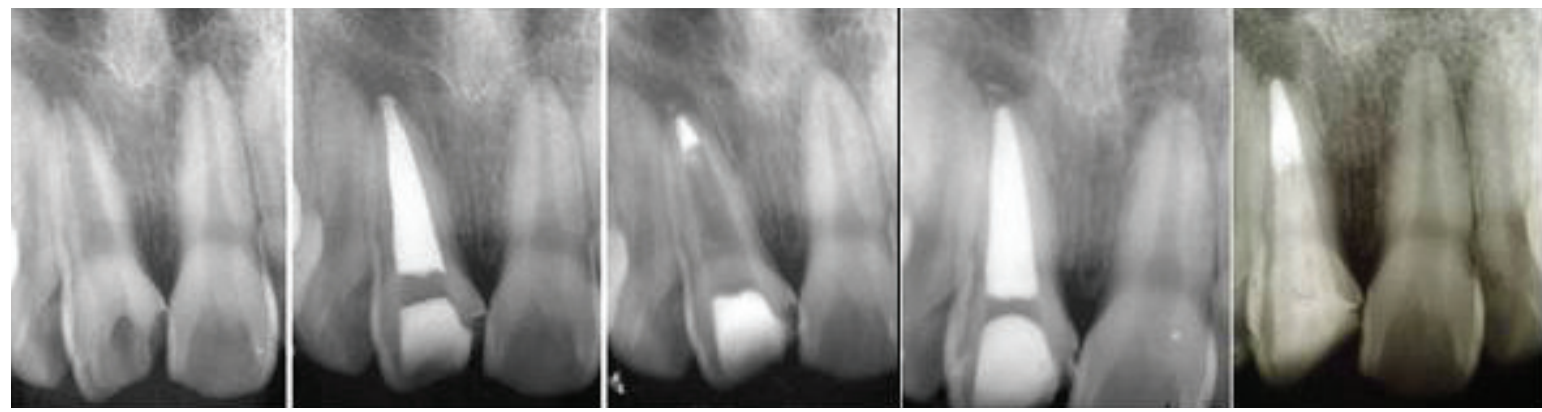

Figure 1. a) initial radiograph; b) root canal dressing with calcium hydroxide; c) MTA plug; d) canal obturation; e) 6-month proservation. 


\section{Clinical case 2}

Female patient, 11 years old, sought the Endodontics Clinic of Escola de Aperfeiçoamento Profissional of Associação Brasileira de Odontologia de Ponta Grossa on 03/27/2004, referred by the public health service of Ponta Grossa, Paraná, Brazil. According to the report by the professional responsible for the patient, she wanted to treat the tooth due to a fistula on the gum. During anamnesis, the patient reported she fell from bunk bed while sleeping. She was immediately taken to an emergency room and dental trauma was found, with mobility, and nothing was done at that time. On clinical examination, there was coronal dimming, fistula on the apical region, absence of pain on vertical and horizontal percussion and, also, on palpation. The tooth did not respond to pulp sensitivity test. Radiographically, it showed periapical radiolucency and open foramen.

The patient underwent treatment, according to the protocol used by the Specialization Course in Endodontics of Escola de Aperfeiçoamento Profissional of Associação Brasileira de Odontologia de Ponta Grossa, as previously described.
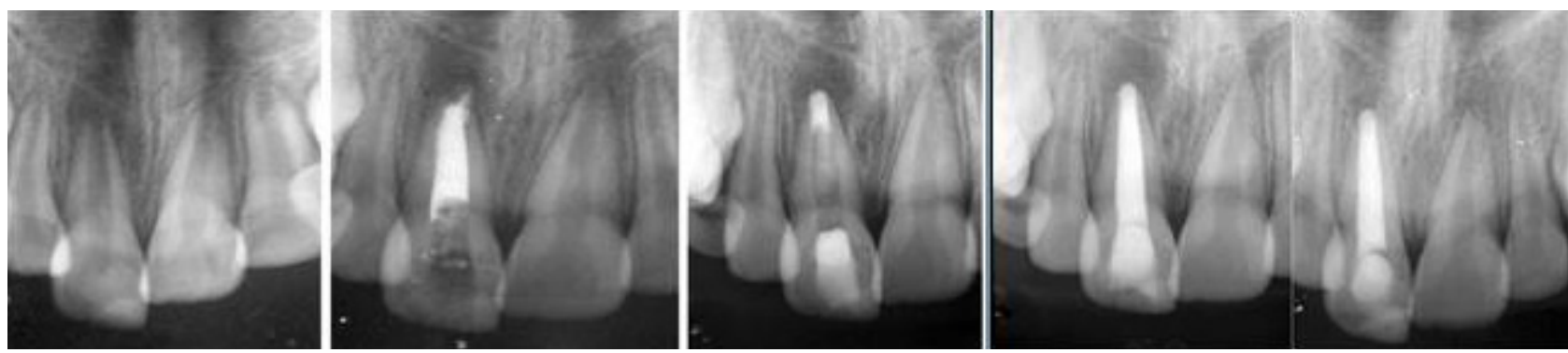

Figure 2. a) initial radiograph; b) root canal dressing with calcium hydroxide; c) MTA plug; d) canal obturation; e) 10-month proservation.

\section{Clinical case 3}

Female patient, 26 years old, sought the private office in Apucarana, Paraná, Brazil, on 11/29/2004 for treating a dimmed tooth with fistula on the apical region. During anamnesis, the patient reported that the tooth was dimmed and asymptomatic, for some years, and she did not recall any trauma, so she never sought treatment before. On clinical examination it was observed that the tooth crown was dimmed, with no decay or fracture, with a fistula on the apical region, mild pain on vertical and horizontal percussion and no pain on palpation. The tooth did not respond to pulp sensitivity test. Radiographically, it showed periapical radiolucency and open foramen.

The patient underwent treatment, according to the protocol used by the Specialization Course in Endodontics of Escola de Aperfeiçoamento Profissional of Associação Brasileira de Odontologia de Ponta Grossa, as previously described.
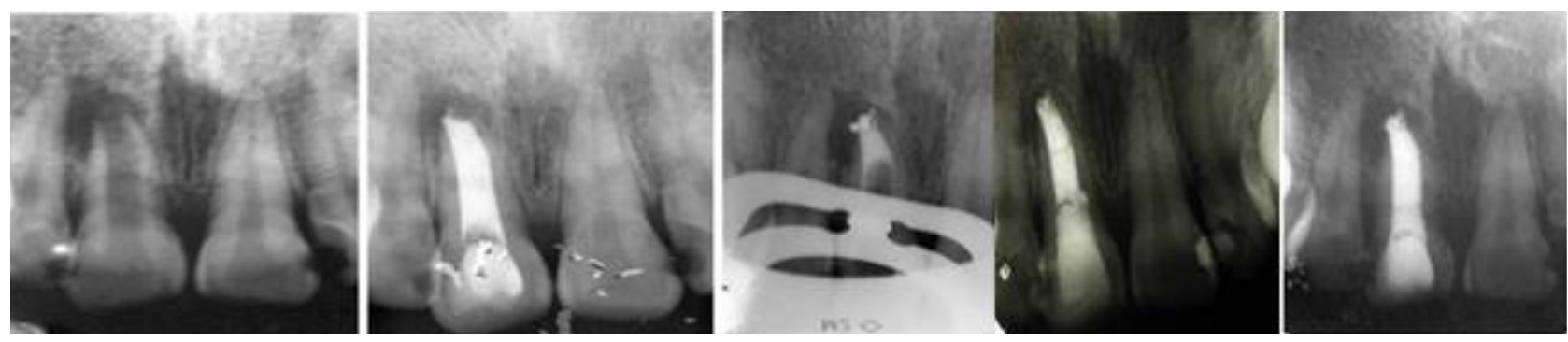

Figure 3. a) initial radiograph; b) root canal dressing with calcium hydroxide; c) MTA plug; d) canal obturation; e) 18-month proservation.

\section{DISCUSSION}

Endodontic treatment of teeth with incomplete root formation and pulp necrosis or open foramina, due to resorption, has been a major challenge for professionals. Before obturating the canal, we have to obtain an apical physical barrier, and this process is named apexification.

The material most commonly used for these cases has been calcium hydroxide, introduced in dentistry by Herman ${ }^{10}$. 
Frank ${ }^{1}$ described an apexification technique where, after disinfection of canals, a calcium hydroxide paste was used, as an intracanal medication. After clinical and radiographic observation of apical closure, the canal was conventionally obturated with gutta-percha and cement.

We can observe in the literature that the principles of Frank's technique ${ }^{1}$ are employed until today, when performing apexification. There is, therefore, unanimity among authors to use calcium hydroxide in cases of incomplete root formation and pulp necrosis.

Webber ${ }^{11}$, in a literature review, cited a technique proposed by the American Association of Endodontists consisting of a calcium hydroxide dressing, for a month, and medication must be changed every 2 or 3 months until observing the formation of an apical barrier.

Holland et al. ${ }^{12}$ have obtained excellent results through apexification, by using Frank's paste and calcium hydroxide, associated with silicone, and these authors conclude their work claiming that regular medication change is needed if we aim to achieve high rates of complete biological sealing.

In the apexification technique with calcium hydroxide, traditionally used, clinical, radiographic, and histologic success have been obtained, but the big disadvantage of this technique is the lengthy period of treatment and the multiple sessions until being able to perform a definitive obturation and providing restorative tooth treatment, resuming patient's masticatory function and meeting her/his aesthetic expectations.

A material with excellent physical and biological properties was introduced in dentistry, MTA, which has as one of its indications the making of an apical plug that will work as a physical barrier, permitting root canal obturation of teeth with open foramina, in a few sessions.

This material is prepared by mixing the powder with distilled water at a 3:1 powder/liquid ratio $^{13}$. The average setting time of MTA is about 165 minutes, longer than amalgam, Super EBA, and IRM ${ }^{14}$. Gray MTA has initial and final setting times significantly longer than white MTA ${ }^{15-16}$. According to the manufacturer, there is already in the market a MTA with significantly shorter setting time, about 15 minutes.

The compressive force of MTA is significantly lower than that of amalgam, IRM, and Super EBA after 24 hours. However, after 3 weeks, there is no significant difference between Super EBA, IRM, and MTA in terms of compressive force ${ }^{14}$. MTA primarily consists of calcium silicate and dicalcium ${ }^{17}$ added with bismuth oxide. As the hydration rate of dicalcium silicate is lower than that of tricalcium silicate $^{18}$, the compressive force ${ }^{14}$ of MTA reaches its maximum several days after mixing ${ }^{19}$. Various factors may influence the compressive force of MTA, including type of MTA, liquid that is mixed with the material, condensation pressure on the material, $\mathrm{pH}$ value of the mixed liquid, and MTA storage condition ${ }^{16,20-22}$.

Shabahang et al. ${ }^{23}$ studied MTA for apexification and concluded that placing an apical MTA cap is a promising alternative to conventional therapy with calcium hydroxide.

Steinig et al. ${ }^{24}$ propose a one-session apexification protocol with MTA as an alternative to the traditional treatment with calcium hydroxide. Apexification can shorten the treatment time from the first session to the final restoration.

Mente et al. ${ }^{25}$, in a retrospective analysis of treatments for teeth with open foramina, using a MTA plug, obtained a rate of $84 \%$ and $100 \%$, respectively, when repairing teeth with and without periapical radiolucency.

Holden et al. ${ }^{26}$ conducted a retrospective study to evaluate the clinical results of Pro Root MTA, used as an apical physical barrier in teeth with open foramina, with 19 patients. These authors concluded that the apical barrier technique is a successful method for obturating teeth with open foramina.

The apical plug thickness varies in different studies from 1 to $10 \mathrm{~mm}^{27-28}$. However, the best results have been reported more frequently with apical plugs from 3 to $5 \mathrm{~mm}$ thick. Studies by Matt et al. ${ }^{29}$ and AlKahtani et al. ${ }^{30}$ reported that apical plugs $5 \mathrm{~mm}$ thick showed the best results.

When used as an apical plug, especially 4 or $5 \mathrm{~mm}$ thick, MTA has shown great sealing capacity27-30.

The protocol of the Specialization Course in Endodontics of Escola de Aperfeiçoamento Profissional of Associação Brasileira de Odontologia de Ponta Grossa recommends a 3-5 mm thick cap, considering data from the literature.

Before placing MTA for apexification, the manufacturer recommends that canals are medicated with calcium hydroxide for 1 week, with subsequent removal by using sodium hypochlorite and instrumentation.

In our procedures, in the end of the first section, we recommend an intracanal medication based on calcium hydroxide with saline, added with iodoform, radiopacifier, for 15 days.

The work conducted by Hachmeister et al. ${ }^{27}$ showed that calcium hydroxide has no effect on MTA sealing ability. 


\section{CONCLUSION}

Apexification is a procedure still performed with some frequency in endodontics. Although good results are achieved by using calcium hydroxide, with successive dressing changes, this technique requires a certain time. With the advent of MTA, we have an alternative procedure, which shows good results within a short period of time.

\section{REFERENCES}

1. Frank AL. Therapy for the divergent pulpless tooth by continued apical formation. J Am Dent Assoc. 1966;72(1):87-93.

2. Selden HS. Apexification: an Interesting case. J Endod. 2002;28(1):44-5. doi: 10.1097/00004770-200201000-00011

3. Weissenseel JA, Hicks ML, Pellen GB. Calcium hydroxide as an apical barrier. J Endod. 1987;13(1):1-5. doi: 10.1016/S00992399(87)80084-5.

4. Schumacher JW, Rutledge RE. An alternative to apexification. J Endod. 1993;19(10):529-31. doi: 10.1016/S00992399(06)81497-4.

5. Coviello J, Brilliant JD. A preliminary clinical study on the use of tricalcium phosphate as an apical barrier. J Endod. 1979;5(1):613. doi: 10.1016/S0099-2399(79)80141-7.

6. Giuliani V, Baccetti T, Pace R, Pagavino G. The use of MTA in teeth with necrotic pulps and open apices. Dent Traumatol. 2002;18(4):217-21. doi: 10.1034/j.16009657.2002.02107.x

7. Simon S, Billiard F, Berdal A, Machtou P. The use of mineral trioxide aggregate in one-visit apexification study. Int Endod J. 2007;40(3):186-97. doi: 10.1111/j.1365-2591.2007.01214.x.

8. Torabinedad M, Higa RK, McKendry DJ, Pitt Ford TR. Dye leakage of four root end filling materials: effects of blood contamination. J Endod 1994;20(4):159-63. doi: 10.1016/ S0099-2399(06)80326-2

9. Torabinejad M, Chivian N. Clinical applications of mineral trioxide aggregate. J Endod. 1999;25(3):197-205. DOI: 10.1016/S00992399(99)80142-3.

10. Hermann BW. Calcium hydroxide als Mittelzum Behandeln und Füllen von Wurvel Kanalen. Diss: Wurzburg, 1920.

11. Webber RT. Apexogenisis versus apexification. Dent Clin North America. 1984;28(4):669-97.

12. Holland R, Souza V, Nery MJ, Bernabé PFE. Comportamento dos tecidos periapicais de dentes de cães com rizogênese incompleta, após obturação de canal com diferentes materiais obturadores. Rev Bras Odontol. 1992;49(3):49-53.

\section{Collaborators}

AE KRÖLING participated in the collection of clinical cases, bibliographical survey, and paper writing. CR BERGER participated in the collection of clinical cases, bibliographical survey, and paper writing. CA PELLISSARI participated in the selection and collection of cases, bibliographical survey, and paper writing. MAJ GOMES participated in the collection of clinical cases, bibliographical survey, and paper writing.

13. Torabinejad M, Watson TF, Pitt Ford TR. Sealing ability of a mineral trioxide aggregate when used as a root-end filling material. J Endod. 1993;19(2):591-5. doi: 10.1016/S00992399(06)80271-2.

14. Torabinejad M, Hong CU, McDonald F, Pitt Ford TR. Physical and chemical properties of a new root-end filling material. J Endod. 1995;21(7):349-53. DOI: 10.1016/S0099-2399(06)80967-2.

15. Chng HK, Islam I, Yap AU, Tong YW, Koh ET. Properties of a new root-end filling material. J Endod. 2005;31(9):665-8.

16. Islam I, Chng HK, Yap AU. Comparison of the physical and mechanical properties of MTA and Portland cement. J Endod. 2006;32(3):193-7. doi: 10.1016/j.joen.2005.10.043

17. Camilleri J, Montesin FE, Brady K, Sweeney R, Curtis RV, Ford TR. The constitution of mineral trioxide aggregate. Dent Mater. 2005;21(4):297-303. DOI: 10.1016/j.dental.2004.05.010.

18. Dammaschke T, Gerth HU, Zuchner H, Schafer E. Chemical and physical surface and bulk material characterization of White ProRoot MTA and two Portland cements. Dent Mater. 2005;21(8):731-8. doi: 10.1016/j.dental.2005.01.019.

19. Sluyk SR, Moon PC, Hartwell GR. Evaluation of setting properties and retention characteristics of mineral trioxide aggregate when used as a furcation perforation repair material. J Endod. 1998;24():768-71. DOI: 10.1016/S0099-2399(98)80171-4.

20. Watts JD, Holt DM, Beeson TJ, Kirkpatrick TC, Rutledge RE Effects of $\mathrm{pH}$ and mixing agents on the temporal setting of tooth-colored and Gray mineral trioxide aggregate. J Endod. 2007;33(8):970-3. doi: 10.1016/j.joen.2007.01.024.

21. Chogle S, Mickel AK, Chan DM, Huffaker k, Jones JJ. Intracanal assesment of mineral trioxide aggregate setting and sealing properties. Gen Dent. 2007;55(4):306-11.

22. Holt DM, Watts JD, Beeson TJ, Kikpatrick TC, Rutledge RE. The anti-microbial effect against enterococcus faecalis and the compressive strength of two types of mineral trioxide aggregate mixed with sterile water or $2 \%$ chlorhexidine liquid. J Endod 2007:33:844-7.

23. Shabahang $S$, Torabinejad $M$, Boyne PJ, Abedi HH, McMillan P. Apexification in immature dog teeth using osteogenic protein-1, mineral trioxide aggregate, and calcium hydroxide. J Endod. 1999:25:1-5. 
24. Steinig $T H$, Regan JD, Gutmann JL. The use and predictable placement of mineral Trioxide Aggregate in one-visit apexification cases. Aust Endod J. 2003;29(1):34-42

25. Mente J, Hage N, Pfefferle T, Koch MJ, Dreyhapt J, Staehle HJ, Friedman S. Mineral trioxide aggregate apical plugs in teeth with open apical foramina: a retrospective analysis of treatment outcome. J Endod. 2009;35(10):1354-9. doi: 10.1016/j. joen.2009.05.025.

26. Holden DT, Schwartz SA, Kirkpatrick TC, Schlinder WG. Clinical outcomes of artificial root-end barriers with mineral trioxide aggregate in teeth with immature apices. J Endod. 2008;35(7):812-7. doi: 10.1016/j.joen.2008.04.003.

27. Hachmeister DR, Schindler WG, Walker WA, Thomas DD. The sealing ability and retention characteristics of mineral trioxide aggregate in a model of apexification. J Endod. 2002;28(5):38690. doi: 10.1097/00004770-200205000-00010.
28. Valois CRA, Costa Jr ED. Influence of the thickness of mineral trioxide aggregate on sealing ability of root-end filling in vitro. Oral Surg Oral Med Oral Pathol Oral Radiol Endod. 2004;97(1):108-11. doi: 10.1016/S1079-2104(03)00359-7.

29. Matt GD, Thorpe JR, Strother JM, McClanahan SB. Comparative study of white and gray mineral trioxide aggregate (MTA) simulating a one-or-two-step apical barrier technique. J Endod. 2004;30(12):876-9. doi: 10.1097/01. don.0000136213.93171.45.

30. Al-Kahtani A, Shostad S, Schifferle R, Bhambhani S. In vitro evaluation of microleakage of an orthograde apical plug of mineral trioxide aggregate in permanent teeth with simulated immature apices. J Endod. 2005;31(2):117-9.

Received on: 17/9/2009

Final version resubmitted on: 13/2/2011

Approved on: 7/4/2011 